\title{
GEOGRAFIA E TERRITORIALIDADES NA UMBANDA: USOS E APROPRIAÇÕES DOS ESPAÇOS URBANOS
}

\section{Geography and territorialities in Umbanda: uses and appropriations of urban spaces}

\author{
Sulivan Charles BARROS ${ }^{1}$
}

\begin{abstract}
RESUMO
Os terreiros afro-brasileiros são considerados como espaços sociais, míticos, simbólicos, em que a natureza e seus fiéis se unem para viver uma realidade diferente daquela que o cotidiano ou a sociedade lhes apresenta como o real, na qual as pessoas que o constituem acreditam. São vistos como lócus da força vital que pode ser conservada, manuseada e transmitida. Suas instalações estão impregnadas do simbolismo religioso e são tidas como extensões da essência vital de suas "entidades" patronas vinculada ao modo de vida urbano, na construção de suas organizações e discursos subalternos e no confronto histórico de suas crenças.
\end{abstract}

Palavras-Chave: cidade; terreiro; simbolismo; umbanda.

\begin{abstract}
The Afro-Brazilian "terreiros" are social, mystical and symbolic places, where the followers of a religion called "umbanda" can make their rituals. In these spaces, these followers can live an alternate reality from the one presented by society, since these places are considered a place as a locus of the vital ancient forces, which can be kept and passed to other people. The "terreiros" insides are full of spiritual symbolism and are extensions of its entities vital essence, allied to the urban way of life, in the construction of their organization and servile speech and in the historical conflict of their beliefs.
\end{abstract}

Keywords: city; terreiro; symbolism; umbanda. 


\section{INTRODUÇÃO}

A diversidade é a característica mais marcante da cidade. É o que lhe imprime contorno e ritmos próprios.

Palco de ensaio do surgimento de novos personagens sociais, da gestação de uma nova possibilidade, da elaboração de novas formas de sociabilidade e interações, da construção de novos sistemas de saber e técnicas de poder, a cidade se apresenta como o lugar em que convivem todas as possibilidades de expressão criadas pela cultura.

É aqui o lugar das relações impessoais do capitalismo com o nepotismo, da família com o individualismo crescente, do isolamento individual com a comunicação internacional, da religião com a ciência e, em termos de espaço físico, dos centros superconstruídos com as periferias vazias, dos arranha-céus com as favelas, da arquitetura tradicional e de estilo com a ultra-moderna, mas, principalmente, a cidade é o lugar em que convivem pobres e ricos, velhos e jovens, mendigos e doutores, católicos e protestantes, ateus e macumbeiros...

Cada grupo social pode construir e reconstruir a cidade criativamente, a partir de elementos selecionados no amplo leque de opções disponíveis na cultura de uma dada sociedade. Ou seja, a cidade pode ser construída (interpretada, analisada e vivida) a partir do trabalho, do lazer, da economia, das festas, do trânsito, da religião e, sempre haverá uma cidade a ser construída conforme se privilegiem aspectos específicos.

\section{O TERREIRO E O URBANO: USOS E APROPRIA- ÇÕES SIMBÓLICAS}

As religiões afro-brasileiras como o candomblé e, em especial a umbanda, fazem parte e participam como instituições reconhecidas e incorporadas no cotidiano da vida urbana brasileira.

Para o grupo religioso que os freqüenta, os terreiros constituem, à sua maneira, ponto fixo, "centro do mundo", em que a noção de espaço sagrado implica na idéia da repetição da "hierofania" que consagrou esse espaço "transfigurando-o, em resumo, isolando-o do espaço profano à sua volta" (ELIADE, 1993, p. 295).
O terreiro é um espaço social, mítico, simbólico, em que a natureza e os fiéis se unem para viver uma realidade diferente daquela que o cotidiano ou a sociedade lhes apresenta como o real, na qual as pessoas que o constituem acreditam. É nesse espaço que se dá a transmissão e aquisição dos conhecimentos da tradição religiosa afro-brasileira.

O terreiro significa, para os seus freqüentadores, um espaço idealizado, divinizado, no qual "orixás" e "guias" baixam, para manifestar ali o encontro desses com a sua comunidade religiosa. É assimilado como um local de vida, de reunião, de participação, espaço social, além de religioso.

Porém, essas casas de culto, na sua maioria, possuem a peculiar propriedade de serem quase "invisíveis" aos olhos dos leigos. Ao contrário das igrejas cristãs, que ocupam pontos de destaque na geografia urbana, os terreiros de umbanda são difíceis de serem encontrados, o que é compatível com o lugar social dessa religião na sociedade.

Embora os terreiros não necessitem de templos especiais para suas instalações, conforme Silva (1995, p. 174):

caracterizam-se por incorporarem em sua lógica de divisão do espaço físico inúmeras concepções cosmológicas relativas ao sagrado e ao profano, ao mistério ou ao segredo e, principalmente, ao poder religioso.

Quase nunca o terreiro é um edifício construído específica e exclusivamente para esse fim. Na maioria dos casos é a adaptação ou o aproveitamento de um espaço no quintal ou na casa do pai ou mãe-de-santo: uma construção no jardim, a ampliação de uma garagem, a adaptação de um quarto, um "puxadinho" nos fundos da casa. O terreiro é, pois, em geral a própria casa de seu chefe, não tanto porque ele mora no terreiro, mas, porque ele transformou sua casa num terreiro ${ }^{2}$.

Isto faz com que os espaços profanos e sagrados nunca estejam totalmente delimitados. Assim como as partes profanas da moradia podem ser usadas religiosamente (uma "consulta" na cozinha ou no quarto, uma cerimônia na sala, etc.) o recinto cerimonial fora das horas de "trabalho" também poderão ser utilizados profanamente (como sala de estar, de costura, de baile,

2 Em trabalho-de-campo realizado na cidade de Codó, no Maranhão, entres os meses de agosto e setembro de 1999, tive a oportunidade de visitar alguns terreiros que "fogem" a essa realidade, de tão grandes eles chegavam até a ocupar quase um quarteirão inteiro da cidade e, em geral, eram freqüentados por políticos, fazendeiros e autoridades locais da região como era o caso das casas de culto Tenda Espírita de Umbanda Rainha de lemanjá e a Tenda Espírita de Umbanda Raio Solar de propriedade dos famosos pais-de-santo maranhenses Bita do Barão e Domingos Paiva, respectivamente. No caso do terreiro de Bita do Barão, alguns "palácios" foram edificados em partes destacadas do terreiro. Inúmeras eram também as imagens, em tamanho grande, das "entidades" espirituais que acabavam por acompanhar os visitantes do portão central da casa até o "palácio" de lansã, em que realizavam os rituais religiosos de caráter público daquela casa. 
de dormir, etc.).

O mesmo ocorrerá com muitos objetos da casa que poderão cumprir um papel religioso ou profano, conforme a ocasião: panelas, pratos, copos e talheres usados cotidianamente têm uma utilização ritual nas cerimônias, uma lata de óleo vazia pode ser utilizada na defumação, uma mesa de centro ou cadeira se transformará em um "mini-congá", etc. Segundo Brumana e González, esta condição se mostra de forma extrema:

O espaço sagrado (do terreiro) deve pactuar com o profano; em potência a maior parte do tempo, bastam uns poucos deslocamentos de móveis e alguns traços de giz no chão para fazê-lo despertar. Essa pendularidade entre os dois mundos não se detém em nenhum momento; da mesma forma que os objetos de uso trivial da casa passam a ser usados nas cerimônias (bandejas, copos, talheres, etc.) o espaço, mais que adotar, embora temporariamente, caráter sagrado ou profano, é um ou outro praticamente ao mesmo tempo, dependendo da intenção, o sentido da ação, de quem por ele transita. Esta passagem tão fluída entre os dois domínios tem seu correlato na também fácil passagem entre atitudes; no meio do ritual ou nos intervalos entre um momento e outro do mesmo, os oficiantes comem, tomam café ou aguardente, fazem brincadeiras, falam de seu trabalho ou de futebol (1984, p. 237).

Os terreiros são considerados lócus do "axé", da força vital que pode ser conservada, manuseada e transmitida. Suas instalações estão impregnadas do simbolismo religioso e são tidas como extensões da essência vital dos orixás ou "guias" patronos do terreiro e, em alguns casos, dedicados, além desses, também a outras divindades.

Silva (1995) sugere que devemos considerar os terreiros como "seres vivos" e, portanto, torna-se necessário de tempos em tempos homenagear esses espaços e sacralizá-los com rituais e sacrifícios apropriados (chamados de "dar de comer ao ariaxé"). Essas instalações ao serem sacralizadas passam também a serem tidas como extensões do "axé" proveniente daquelas divindades que receberam as oferendas rituais.

Os limites do terreiro não se resumem ao espaço fechado entre os muros. Todavia, os limites do terreiro são os limites espaciais de um grupo social. Isso é, as fronteiras desse espaço sagrado simbolizam também os espaços "naturais" ou de "natureza construída" que Ihes estão mais próximos, tais como praias, cachoeiras, matas, ruas, cemitérios e encruzilhadas, dentre outros, onde também se realizam cerimônias religiosas.

Cada um desses espaços "naturais" ou de "natureza construída" estão relacionados a um grupo de orixás ou "guias": a mata dos caboclos; a cachoeira de Oxum e das caboclas do rio; a praia de Iemanjá, marinheiros e sereias; o cemitério de Obaluaiê e a determinado grupo de exus; a encruzilhada dos exus e das pombas-giras; a rua de exus, pombas-giras e malandros.

Ao analisar esses limites máximos do terreiro, podem-se verificar também as fronteiras espaciais de uma sociedade. Para Maggie (2001, p. 14),

[...] o mar, o rio, os caminhos, a floresta e o cemitério (limite máximo entre a vida e a morte). Mas, de outro lado, notam-se pontos de encontro e contato, nos quais a mata se encontra com a cachoeira, o mar com o rio, onde os caminhos se encontram e, finalmente, onde os vivos se encontram com os mortos. Assim, esses limites marcam também o local de encontro ou de reunião do grupo, simbolizado nos encontros da natureza.

Os "ebós", também conhecidos como "despachos", são os elementos mais visíveis e freqüentes que saem do terreiro para a rua, sendo o principal responsável pela identificação de "forças místicas" nos espaços da cidade.

Exu torna-se o principal homenageado pela sua característica de mensageiro entre os homens e os deuses. Suas principais oferendas são galos de cor escura, farofa, carne bovina, whisky, conhaque, aguardente ou batidas diversas. Ele recebe suas oferendas principalmente nas encruzilhadas. Conforme Touré e Konaté:

Ponto de encontro dos homens entre eles e dos homens com os gênios, a encruzilhada [...] concentra e condensa as forças dos quatro pontos cardeais. Ninguém pode viver sem passar por uma encruzilhada (apud SILVA, 1995, p. 228).

Em geral a entrega desses despachos realizase nas encruzilhadas e cemitérios por volta da meianoite, pois esse horário simboliza a transformação, ou o limite entre o dia que termina e o outro que se inicia, e pelo fato de que as ruas da cidade tornam-se menos movimentadas.

Em termos espaciais, e com toques freudianos, deve-se levar em conta que as encruzilhadas utilizadas pelos exus, devem ser em forma de " $X$ ", porque aquelas em forma de "T" são dedicadas às pombas-giras, para resolverem problemas de ordem amorosa ou sexual. Para elas as principais oferendas são flores vermelhas, cigarros, anis, champanhas ou licores diversos.

O simbolismo da encruzilhada em " $X$ " e em "T" com exu e pomba-gira respectivamente (conforme figura 1), parece estar associado à sexualidade dessas 
"entidades".

Exu, segundo o mito, movimenta-se no tempo e no espaço utilizando o ogó (pênis). Sendo a pomba-gira um exu feminino, não possuindo, portanto, o pênis, talvez por isso Ihe "falte" um caminho (SILVA, 1995, p. 228).

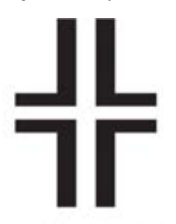

Encruzilhada de Exu

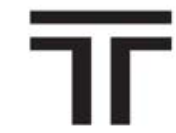

Encruzilhada de Pomba-Gira

FIGURA 1 - ENCRUZILHADAS EM "X" E EM "T" (IMAGEM DO AUTOR)

Outras encruzilhadas serão utilizadas para a entrega de agrados ou "descargas", na forma seguinte ${ }^{3}$

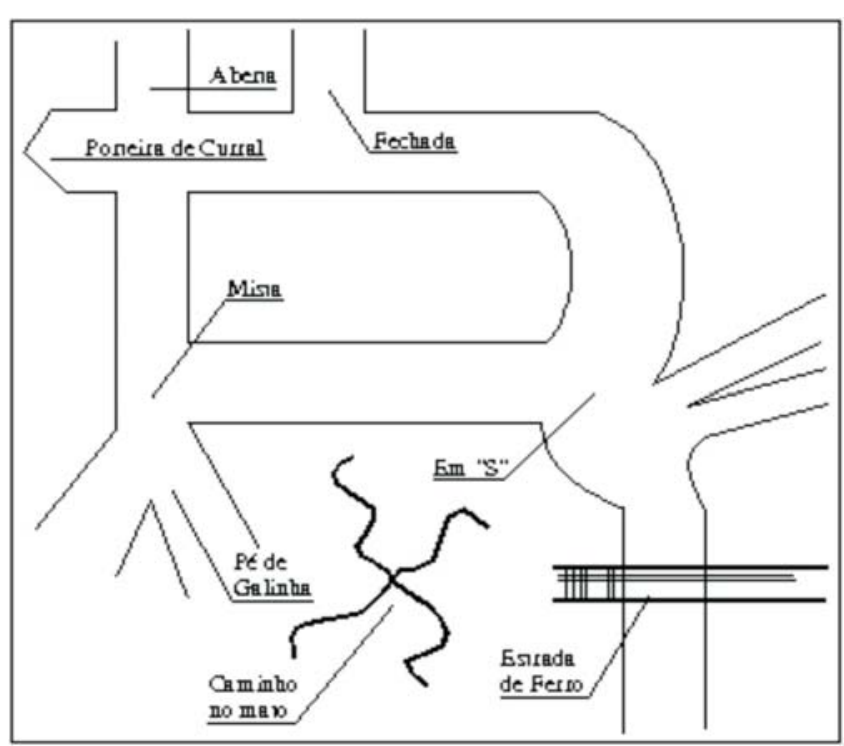

FIGURA 2 - OUTRAS ENCRUZILHADAS (IMAGEM DO AUTOR)

(conforme figura 2):

Encruzilhadas abertas: para todos os exus (indistintamente);

Encruzilhadas fechadas: para todos os exus (indistintamente);

Porteira de curral: Exu das 7 porteiras;
Encruzilhadas mistas: exus-mirins, etc.;

Encruzilhadas em "S" ou curvas": Exu Tira Teima;

Encruzilhadas em "pé de galinha": Dona Pomba Gira;

Encruzilhadas de estrada de ferro: Dona Maria PadiIha;

Encruzilhadas de caminho de mato: Dona Maria Molambo.

As outras "entidades" da umbanda também irão requerer suas oferendas em locais apropriados.

Os caboclos gostam de milho verde em espiga ou seco a granel, água de coco, eucalipto, girassol, sândalo, frutas diversas, charutos e aguardente com mel. Seus espaços por excelência são as matas, preferencialmente as fechadas.

Para os boiadeiros destinam-se as mesmas oferendas que para os caboclos, com exceção da aguardente, que eles preferem puro. Os melhores locais para os boiadeiros são as matas, os caminhos de mato e em área rural próximo a currais de gado.

Aos preto-velhos são destinados em suas oferendas feijoadas acompanhadas com gergelim, rapadura e o café sem açúcar. São, também, oferecidos o fumo-decorda e vinhos diversos. Seus locais são os ambientes de bambuzais, locais próximos a igrejas católicas e para alguns, o cemitério.

Para a beijada (crianças), o melhor local para depositar as oferendas são os jardins e praças floridas. Essas são em geral frutas e doces diversos. Gostam também de guaraná, água com açúcar, flores miúdas e essência de maçã.

As "entidades" da "linha" da água como os marinheiros e as sereias têm como seu "habitat" natural o mar. Contudo, em regiões distantes do litoral, as oferendas podem ser depositadas próximas a rios, cachoeiras ou águas correntes. Para os marinheiros se oferece leite de coco, arroz mole, cerveja, água misturada com sal e cigarros. Para as sereias o ideal é ofertar os mais diversos tipos de flores e artigos de higiene pessoal e beleza, tais como sabonetes perfumados, perfumes, espelhos, batons, etc.

As "entidades" baiano(a)s gostam muito de farofa com dendê, além de água de coco. Em geral, se depositam as oferendas para esses em caminhos de mato

3 Dados fornecidos por pais e mães-de-santo umbandistas.

4 Segundo meus interlocutores, nas curvas em "S" nunca se deve atravessar as encruzilhadas em diagonal, principalmente as de dentro do cemitério. Ao utilizar-se de uma porteira de curral, deve-se entrar pelo lado direito e sair pelo esquerdo. Caso esses preceitos não sejam respeitados, os fiéis poderão sofrer conseqüências espirituais. 
e ambientes descampados.

Para os personagens ciganos e ciganas é oferecido o mesmo que se oferta para os exus e pombas-giras. Seus locais são os mesmo daqueles, as encruzilhadas. Outros, entretanto, preferem locais descampados.

Para os "malandros" se oferece o mesmo que para os exus. Seus locais preferidos são aqueles próximos a bares e "inferninhos".

As "entidades" da "linha do oriente", segundo informações dos meus interlocutores, não aceitam oferendas rituais. Esses fazem parte da umbanda esotérica, em que se condena esse tipo de relação fiel-"entidade".

O terreiro, portanto, é o ponto de encontro dos homens com os seus "guias". A terra dos homens opõese à terra dos orixás, o terreiro, porque nela se dá esse encontro dos homens com os deuses, simbolizando também nos pontos de encontro da natureza, pois o terreiro é também, como se pode perceber, mar, cachoeira, rio, caminhos, matas, floresta, encruzilhadas, ruas e cemitério.

A casa em que os médiuns realizam a maior parte dos rituais, o terreiro propriamente dito, tem limites espaciais bem demarcados. Em geral é dividido em uma parte interna e outra externa - o lado de dentro e o lado de fora.

O terreiro também é casa não apenas do pai ou mãe-de-santo, mas também de muitos de seus filhos consangüíneos e espirituais. Ele é simultaneamente templo e moradia. A família de santo divide os cômodos de seu cotidiano profano com o espaço sagrado de seus deuses.

O cômodo principal do terreiro é chamado de "barracão", o salão de encontro de homens e divindades nas "giras" públicas da casa. O barracão, por sua vez, é dividido em uma parte sagrada, a sala do "congá", e outra profana, a sala da "assistência"5.

As imagens dos santos, orixás e "guias" estão na sala do congá, na parte interna do barracão e outras ainda se encontram nos "roncós" em que ficam os "pejis" (altares) e os "assentamentos" (objetos e símbolos rituais das "entidades" da casa), com exceção dos exus, que, em geral, são colocados no lado de fora.
Na maior parte dos terreiros, a casa de exu fica perto da porta de entrada. Pois é exu o guardião da porta da rua e das encruzilhadas. É na casa de exu que se faz o "despacho" para poder iniciar as "giras". Esses são postos na parte mais marginal do terreiro, do lado de fora.

Esses limites são marcados não apenas espacialmente com divisões entre cada uma das partes, com locais específicos para determinadas "entidades", mas também por comportamentos rituais denominados de "ritos de passagem" (VAN GENNEP, 1978). Nas palavras de Rosendahl: "os dois espaços, sagrado e profano, estão numa relação de ideal e comum, de excepcional e cotidiano" (1996, p. 32), em que a passagem de um plano para o outro deve ser feito por meio de um estágio intermediário, de um "sacrifício".

Tais "ritos de passagem" podem ser percebidos quando para transpor a porta que dá acesso ao espaço sagrado, os adeptos e clientes, localizados no lado profano, devem, primeiramente, retirar os calçados. Para sair da parte sagrada, os médiuns não podem "dar as costas" para o "congá".

Para Van Gennep (1978), esses "ritos de passagem" de ordem material tornam-se ritos de passagem espiritual: "não é mais o ato de passar que constitui a passagem, e sim uma potência individualizada que assegura imaterialmente esta passagem" (p. 38). Assim, atravessar essa porta significa ingressar num mundo novo.

No início de cada sessão, as partes marginais, entradas e saídas do barracão são tratadas com atos especiais. Todos os cantos do terreiro são "defumados", numa forma de purificação do ambiente. Vale ressaltar que em todos os altares da casa quer sejam internos e ou externos ao barracão se ascendem velas brancas e, em alguns desses, se ofertam oferendas rituais, como é o caso do "despacho" de exu.

A partir da participação de festas públicas percebem-se outros ritos que denotam uma espécie de "espacialidade de abertura ritual". As "entidades" quando "incorporadas" em seus "cavalos", passam a realizar uma série de cumprimentos rituais: cumprimentam a porta ou portão da casa (o mundo externo, profano), o "entoto" (ponto central do barracão e, portanto do espaço sagrado estabelecido no terreiro), os atabaques (instrumentos utilizados para louvar e chamar os deuses para o mundo dos homens) e a mãe ou pai-de-santo

5 É o local onde o público permanece para ser atendido pelas "entidades" em momento oportuno. Em alguns terreiros, aqueles maiores, é possível que ocorra uma divisão sexual da "assistência", elemento característico do culto umbandista.

6 No candomblé os "roncós" são utilizados para recolher os filhos-de-santo durante o seu processo de iniciação. 
(saudação ritual a pessoa chefe do terreiro).

Contudo, esse mesmo procedimento ritual não é efetuado nas "giras de exus", postos esses serem avessos às regras de comportamento de qualquer espécie. Ao lado disso, o ideal é que essas "giras" sejam realizadas em outros locais que não aqueles utilizados ritualmente pelas outras "entidades". Não é raro um exu descer numa "gira" de caboclo, preto-velho, etc. e ser expulso pelo pai ou mãe-de-santo que os repreendem dizendo que ali não é o lugar deles e que esses devem respeitar.

Quando o centro dispõe de espaço físico, acabam construindo um local próprio para a realização das "giras" de exu. Outras casas, por não disporem desse espaço físico ou até mesmo para não terem problemas com a vizinhança, acabam realizando esses rituais fora do terreiro, nas "encruzas" do perímetro urbano do qual o terreiro faz parte, porém, naquelas que possam apresentar pouca movimentação e maior segurança.

Quando nenhuma dessas alternativas se torna possível, o grupo religioso acaba mesmo por adotar uma estratégia "culturalmente subversiva", porém nãoilegal. Aí se utiliza o mesmo espaço, porém, tomando todos os cuidados necessários para que perigos não recaiam sobre médiuns e clientes: fecham-se as cortinas do "congá" ou, simplesmente, encobre-o com tecidos de cor branca. Colocam-se os apetrechos rituais dos exus e pombas-giras (imagens, punhais, facas, bebidas, charutos, cigarros, etc.) em locais o mais distante possível do "congá" da casa, evitando que os exus se aproximem do mesmo.

Por outro lado, ao "ampliar" os limites espaciais do terreiro, o grupo religioso se apropria simbolicamente de certos locais da cidade tais como as "encruzas" como é o caso das "giras" de exu, ou inúmeros outros, do qual as "entidades" espirituais se identificam para o depósito de suas oferendas e "despachos".

Para tal, exige-se um conhecimento prévio de quais são os locais da cidade à qual o grupo religioso está circunscrito e que sejam mais propícios para a realização dos seus ritos, evitando situações que poderiam ser constrangedoras e até mesmo perigosas.

Sendo assim, as cidades passam a ser pensadas como parte integrante do cosmos umbandista, que extrapola o domínio dos terreiros. Ao demarcar seu território com ações e práticas religiosas, o grupo religioso identifica-se com a cidade, criando uma identidade vivida/espacial.

Dessa forma, as cidades passam a se apresentar não apenas como o lugar da convivência dos homens entre si, mas também de convivência dos homens com os seus deuses, criados e invocados, principalmente, pelas suas oferendas rituais.

\section{O TERREIRO COMO SISTEMA DEFENSIVO: SUAS "GIRAS"}

Os terreiros que compõem a geografia da cidade são ricos em variações doutrinárias e seus participantes são exímios mestres na arte de inovar, de assimilar influências, de compor rituais.

As regras e os ritos litúrgicos variam de terreiro para terreiro. Embora existam federações umbandistas que tentam uniformizar os rituais, o que se verifica na prática é a existência dessas casas religiosas que funcionam independentemente das federações, realizando seus próprios rituais litúrgicos de acordo com o aprendizado do pai ou da mãe-de-santo.

Essa autonomia dos terreiros é sem dúvida o ponto crucial dessa permeabilidade à variação que se encontra na umbanda. E aqui cabe uma observação: não há dúvida de que todos os grupos sociais são sujeitos a influências culturais diversas. Mas o processo de assimilação de influências vai estar de certo modo condicionado à forma de organização interna do grupo.

É obvio que na dinâmica das relações sociais não há qualquer influência cultural que seja simplesmente "engolida" sem o devido processo de "digestão", isso é, adaptada às experiências de vida dos grupos, refletida à luz de sua história e de suas tradições.

Para Birman, esse processo de "digestão" que implica refazer e reordenar o sentido dos produtos culturais diversos é mais simples no meio umbandista graças às particularidades no plano de organização dessa religião. Segundo a autora,

É mais fácil para um pai-de-santo adaptar uma reza que escutou num programa de rádio, incorporar um novo "ponto cantado" que aprendeu num festival de cantigas de umbanda do que uma comunidade de fiéis, numa paróquia católica, realizar qualquer modificação nos rituais de sua igreja (1985, p. 81).

As variações interpretativas, a invenção, a recriação na umbanda são um processo dinâmico e constante. Novas "entidades", novas características, novos tipos estão permanentemente em elaboração a partir da mesma matriz.

Torna-se quase impossível enumerar todas as possibilidades interpretativas que surgem nesse con- 
texto religioso. Contudo, nada impede, de se relacionar com certos contextos sociais determinadas ênfases de padrões interpretativos.

De fato, os terreiros freqüentados, em geral, por camadas populares tendem a ver as "entidades" do culto sem comprometê-las com uma visão moralizante. E, ainda, são nesses mesmos terreiros que o caráter polivalente e ambíguo das "entidades" ressaltam mais.

Já nos terreiros em que há o predomínio das camadas médias é maior o lugar dado a interpretações que destacam o valor moral das "entidades" e é maior também a preocupação com a "evolução" dos espíritos e dos homens.

Porém, um ponto em comum: a geografia do terreiro, assim como as práticas que nele se desenvolvem quer sejam mais voltadas à diversidade como nos terreiros populares, quer sejam mais comprometidas com uma visão moralizante como nos terreiros médios, eles destinam-se, antes de tudo, a manter fora ou expulsar algo que ameaça invadir ou que invadiu um espaço, seja ele físico, ritual ou pessoal.

Esse movimento entre um interior ameaçado e um exterior ameaçador é a chave de todo o sistema umbandista. Dessa forma, pode-se analisar o terreiro como a representação de uma pequena sociedade cujas fronteiras estão sempre sendo ameaçadas.

Como se pode perceber, a umbanda não tem a pretensão de combater a desordem no mundo ou de instaurar ou restaurar uma ordem universal, homogênea, abstrata. Para a umbanda - e esse é o ponto em que mais claramente ela se mostra como expressão da subalternidade - esse mundo mais amplo ou é desordenado ou possui uma ordem que lhe é própria e inquestionável; tanto num caso como no outro, é uma região incontrolável.

O máximo que pode ser feito, segundo essa concepção religiosa, é ordenar e controlar ambientes restritos e privados que deixam fora de si tanto a ordem como a desordem exterior. A umbanda irá dedicar grande parte de seus esforços, portanto, ao soerguimento de barreiras contra o "exterior".

A extrema proximidade entre as esferas do profano e do sagrado que o culto umbandista apresenta, exige por outro lado, a operacionalização de mecanismos altamente ritualizados para a instauração, a segregação e delimitação dessa última.

Os "cuidados" rituais das práticas umbandistas buscam basicamente a delimitação do tempo e do es- paço frente a duas fontes de intrusão: a) a do mundo profano; b) a de forças negativas incontroladas pelo terreiro. É o êxito no primeiro item que permite enfrentar o segundo. Ou, dito de modo inverso, o suposto efeito dessas forças negativas incontroladas pode ser diagnosticado como produtos do não-cumprimento dos diferentes rituais de limpeza quer seja do espaço físico e sobrenatural e do grupo inserido nesse contexto.

A própria utilização do espaço físico, como já visto anteriormente, pelo terreiro explicita os cuidados rituais e está a seu serviço. A casa de exu, e pombagira, se localiza sempre fora do recinto cerimonial e junto à porta da rua. Essa disposição expressa os dois elementos centrais do perfil simbólico das "entidades" da "esquerda": força e perigo.

O lugar da casa de exu junto à porta da rua tornase bem estratégico, pois é o resultado do compromisso entre a necessidade que o terreiro tem da força dessas "entidades" e a dificuldade de seu controle (eles são potencialmente perigosos). O poder de exu aqui está dirigido para fora; essa é razão de seu lugar liminar, sua posição de "guardião da porta", de "protetor" do terreiro.

Se, por ventura, este assentamento de exu não existisse, o terreiro perderia uma enorme e insubstituível proteção contra as ameaças que vem de fora. Nas palavras de um pai-de-santo:

A esquerda pra nós é o primeiro escudo que a gente tem no terreiro, que é representado pela casinha do moço e da mulher [exu e pomba-gira]. [...] É a defesa que a gente tem pra controlar os perigos e malefícios que vem do mundo de lá de fora (Pai-de-santo $A$. $X$., em entrevista, Brasília/DF, ago./2003).

A razão da ausência do assentamento de exus e pombas-giras dentro do recinto sagrado, está associada também à falta de controle sobre eles. Segundo alguns dos meus interlocutores:

Exu dentro de casa é problema na certa. É muita bagunça e confusão. Dá muita briga. Se eles [exus e pombas-giras] entrarem dentro de casa, eles tomam conta de tudo aqui e não tem "guia" de luz que possa dar jeito não. Então é melhor eles ficarem do lado de fora mesmo. Lá a gente trata bem eles e eles ajudam nós (Pai-de-santo A. X., em entrevista, Brasília/DF, ago./2003).

Bom, a gente tem que manter eles [exus e pombasgiras] do lado de fora, sempre vigiando e tratando bem deles. Dando a bebidinha e a comidinha pros moços e pras moças na hora certa, aí não vai ter problema. Agora repare, se por exemplo, uma pessoa assentar a moça [pomba-gira] dentro de casa, é bagunça, é putaria 
na certa. Aqui mesmo na minha casa tem umas meninas moças, muito bonitas e se a pomba-gira entrar aqui dentro, essas meninas vão é se perder, vão arrumar é um monte de macho e aqui vai virar é um puteiro, com o perdão da palavra. E eu não quero esse futuro pra elas não, e nem pra minha casa, portanto, eu cuido direitinho deles é do lado de fora mesmo, pra evitar esse tipo de confusão, não é não? (Mãe-de-santo $O$. X., em entrevista, Brasília/DF, julho/2003).

O ritual litúrgico umbandista é mais conhecido pelo termo "gira". As "giras" de trabalho ou caridade são sessões públicas realizadas no interior do "barracão", em seu recinto sagrado, na área do "congá", em que os "guias" "descem" em seus "cavalos" para atender ao público.

A longa abertura das "giras" destina-se a inscrevê-las numa zona de segurança. Realiza-se aqui todo um mecanismo de defesa cerimonial.

Embora possam existir pequenas variações de terreiro para terreiro, a seqüência ritual é mais ou menos a seguinte ${ }^{7}$ :

a) Antes de começar qualquer preparação para o início das "giras", todos os médiuns devem fazer a "limpeza de corpo", mais conhecido como "banho de descarrego" (de água com ervas ou com sal grosso).

b) Despacho de exu, para pedir proteção e, ao mesmo tempo, para afastá-los das "giras".

c) Defumação, nos quatro cantos do barracão e diante de cada participante, incluindo a "assistência" (público em geral).

d) Canto de abertura dos "trabalhos", o hino da umbanda, orações para pedir permissão e proteção para os "trabalhos" rituais tais como o padre-nosso, ave-maria, prece de cáritas (de tradição kardecista), etc.

e) Saudação: o corpo do médium saúda em primeiro lugar o "congá" e, em seguida o chefe espiritual do terreiro (pai ou mãe-santo), pais e mães pequenos (segundos na hierarquia) e cambonos (auxiliares do culto).

f) "Pontos cantados" de "descida" das "entidades", acompanhados pelos atabaques e por palmas. Primeiramente, canta-se para os orixás do candomblé. Seguindo uma seqüência ritual. Cada terreiro tem uma seqüência própria de louvor aos orixás, isso é, canta-se primeiro para o orixá mais importante da casa, depois para o outro, até o último a ser homenageado, seguindo uma seqüência ritualística. Exemplo: primeiro, Xangô, segundo Oxum, terceiro, Ogum, etc. (essa seqüência varia de terreiro para terreiro).

g) Após louvar aos orixás, cantam-se para as "linhas" da umbanda que irão "trabalhar" naquele dia. Exemplo: Se naquele dia tiver três "linhas" para "trabalhar", fica a critério do pai ou mãe-desanto quem virão em primeiro, em segundo e, em terceiro. Os médiuns, "tomados" pelas suas "entidades" cantam, dançam, cumprimentam alguns membros da casa.

h) Após o "toque", essas "entidades" dão "passes" e consultas à médiuns não "incorporados" e à "assistência".

i) "Pontos cantados" de subida para os espíritos da "linha" que acabam de "trabalhar", imediatamente chama-se outra, e assim sucessivamente.

j) Saudação final, como no início, canto de encerramento e orações.

k) Despedida dos médiuns e da "assistência".

Porém, nem tudo é paz e amor. A essas sessões, em que espíritos de caboclos, preto-velhos, crianças "descem" para fazer o bem, contrapõem-se outras práticas que recebem o nome de "demanda".

Muitas vezes os problemas que as pessoas enfrentam (desavenças familiares e conjugais, doenças, dificuldades no trabalho, etc.) são atribuídos à inveja, mais concretamente, a "trabalhos" que seus inimigos encomendam a determinados espíritos da "esquerda".

Os "guias" de luz não aceitam esse tipo de solicitação, geralmente creditada a exus e pombas-giras espíritos pouco evoluídos que, em troca de oferendas, não hesitam em fazer o mal.

As "giras" também passam a servir no enfrentamento dessas "demandas". Para isso é preciso pedir ajuda às "entidades" que só trabalham na "direita", às quais se fazem então as oferendas. Às vezes o "trabaIho" é dirigido ao próprio espírito que se acredita ser o responsável do malefício, com o objetivo de atraí-lo e até mesmo fazê-lo mudar de lado, ou ao outro, também da "esquerda", que passa a representar os interesses da parte prejudicada.

7 As informações que aqui se encontram seguem as observações de campo realizadas em terreiros de umbanda em mais de dez anos de pesquisa (Barros, 1997; 2000; 2004; 2005). 
Alguns espíritos da "esquerda" acabam invadindo as "giras" que não lhe são destinadas. Essas "entidades" quando "incorporam" algum médium, são convidados pelo espírito responsável pela "gira" para se retirar, geralmente são as "entidades" de "frente" do pai ou mãede-santo, caso esses não estejam "incorporados", são eles próprios os responsáveis para a expulsão daquelas "entidades" que não foram convidadas.

Em algumas ocasiões esses espíritos se rebelam e geram dificuldades para irem embora, afirmam que só sairão quando quiserem e que ninguém manda neles. Em situações como essas, as "entidades" são geralmente tratadas com muita hostilidade e são conduzidas à casa de exu, do lado de fora do "barracão", até que se "desincorporem" do médium que eles "possuíram". Quando os médiuns voltam a si, eles são repreendidos, para que tenham mais "firmeza" (concentração) na "gira" e que evitem situações como essas que são, antes de tudo, constrangedoras tanto para o terreiro, quanto para os próprios médiuns.

Como é possível perceber o sistema de proteção que os terreiros constroem em torno de si mesmos e de suas práticas rituais é elaborado por meio de uma série de ações e objetos: ervas para queimar ou maceradas na água, defumação, banhos, orações, benzimentos, canções ("pontos cantados"), velas, invocações, oferendas, desenhos ritualísticos ("pontos riscados") etc. Essa lista é certamente incompleta.

Esse conjunto de precauções que é utilizado pelos terreiros é o que determina, juntamente com outras práticas ritualísticas (como por exemplo, o desenvolvimento dos médiuns, de seus orixás e demais "guias de frente"), o que os umbandistas chamam de "segurança" e "firmeza" de um agente ou de um terreiro. Essas noções fundamentais estabelecem o âmbito de proteção no qual a ação ritual pode ser realizada sem qualquer tipo de problema.

\section{CONSIDERAÇÕES FINAIS}

É possível indagar se as religiões afro-brasileiras espelham essas condições históricas e sociais em sua formação: primeiro caracterizaram-se por serem religiões de subalternos (em princípio religião de escravos, depois de negros livres marginalizados, mais tarde de pobres urbanos) que se formaram também como religiões subalternas ao catolicismo que, até aquele momento, aparecia como a religião que dava identidade a grupos particulares e não a sociedade brasileira como um todo.
Mais tarde, quando os cultos afro-brasileiros rompem com as barreiras de cor, geografia e origem, produzem-se suas novas modalidades de caráter universalizado, transformando-se agora em religião para todos, independentemente de cor e geografia, ainda que esses todos sejam, em sua grande maioria, os excluídos. Posteriormente, essas diversas formas de religiosidade negra locais, todas eivadas de sincretismos católicos, e anos mais tarde com o espiritismo kardecista, originou a chamada macumba carioca e entre as primeiras décadas do século passado, a umbanda.

Quem já teve a oportunidade de assistir a uma "gira" de um terreiro umbandista pode perceber, no ritual e no ambiente, a presença de elementos de várias religiões. No altar principal, chamado de "congá", encontram-se imagens de Jesus Cristo, Nossa Senhora, santos como São Lázaro, São Jorge, Cosme e Damião, Orixás, ao lado de estatuetas de Buda, lemanjá, índios, ciganos, preto-velhos e, mais dissimuladas, representações que sugerem a figura do diabo (representando os exus e as pombas-giras). Encontram-se, também, nesses "congas", objetos próprios do rito umbandista ("pembas", "guias", "patuás", etc.), bem como, velas brancas, flores e por vezes ícones cívicos, como a bandeira nacional.

Ali, no espaço sagrado do terreiro, rezam-se padre-nossos, ave-marias e invocam-se os orixás e as "entidades" da umbanda; os espíritos "descem" nos iniciados por meio do transe, provocado pelo toque dos atabaques, cantigas ("pontos cantados") e sinais cabalísticos desenhados no chão ("pontos riscados"). A sessão começa com a defumação da sala; durante a cerimônia os médiuns, tomados por seus "guias", dançam, fumam charutos ou cachimbos, dão passes e conversam com o público presente. A cor das roupas é predominantemente branca, mas não faltam colares de todas as cores, chapéus de couro, de palha, dentre outros acessórios rituais.

O culto é composto de músicas e danças sagradas. Os atabaques marcam o ritmo, os médiuns cantam o "ponto" sob a liderança da mãe ou do pai-de-santo, dançam em roda, e recebem as suas "entidades" espirituais, funcionando como seus "cavalos" e "aparelhos". Além de se expressarem dançando a sua energia vital (segundo a concepção dessas comunidades religiosas), como ocorre com os orixás do candomblé, os "guias" da umbanda, ao contrário daqueles, se apresentam para dar conselhos aos fiéis que deles se aproximam. Orientam esses e purificam-os por meio de "passes", protegendo-os de possíveis ataques místicos de que são ou poderão se tornar vítimas. 
Os terreiros de umbanda tornam-se, assim, centros de avaliação e de resolução de uma infinidade de pequenos conflitos que afligem as pessoas em seu cotidiano profano. São especialistas na identificação das causas dos infortúnios e profundos conhecedores da psicologia social local. Ajudam-na a conformá-la, inclusive, emprestando-lhes um sentido maior. As competições e os conflitos do cotidiano, cujos resultados desiguais semeiam a inveja, o ódio e o ressentimento, resultam na produção de feitiços, ou mesmo na simples geração de negatividades que fazem o mal. O povo da umbanda (dir-se-ia o povo brasileiro, em larga escala) leva a sério os termos "feitiço", "carrego" e "olho grande".

Dessa forma, segundo os códigos do panteão umbandista, o desenvolvimento urbano não é necessariamente obstáculo ou impedimento ao pensamento mágico/religioso. Não se trata de ruptura entre religião e secularização ou entre magia e racionalidade, mas de uma continuidade possível, pelo diálogo entre práticas, valores e significado destoantes, conflitivos ou convergentes, que caracterizam a vida multidimensional da cidade.

\section{REFERÊNCIAS}

BARROS, S. C. Brasil Imaginário: umbanda, poder, marginalidade social e possessão. Tese (Doutorado em Sociologia). Departamento de Sociologia, Universidade de Brasília, Brasília, 2004. . Encantaria de bárbara soeira: a construção do imaginário do medo em Codó/MA. Dissertação (Mestrado em Sociologia). Departamento de Sociologia, Universidade de Brasília, Brasília, 2000. . Urbanização e umbanda: o espaço dos ho-

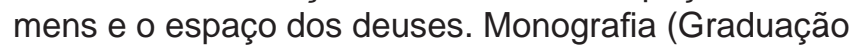
em Geografia). Departamento de Geografia, Universidade de Brasília, Brasília, 1997.

BIRMAN, P. O que é umbanda. São Paulo: Brasiliense, 1985. [Coleção Primeiros Passos].

BRUMANA, F. G.; MARTíNEZ, E. G. Marginalia sagrada. Campinas: Ed. Unicamp, 1991.

ELIADE, M. Tratado de história das religiões. São Paulo: Martins Fontes, 1993.

SILVA, V. G. da. Orixás da metrópole. Petrópolis: Vozes, 1995.

VAN GENNEP, A. Ritos de passagem. Petrópolis: Vozes, 1978. 